\title{
SECURITY AS PUBLIC INTEREST IN CONSTRUCTION LAW
}

\author{
Stawomir Zwolak
}

\begin{abstract}
Polish construction law refers to the public interest in an indirect way, which consists primarily of value within a framework of security. The concept of security in construction law covers a range of issues and is a term quite wide. The special importance of safety results from its fundamental importance for society. The need to ensure security in the construction industry, leads to the need to balance the public interest and the individual. Respecting the public interest expressed in security, it is an essential prerequisite for restrictions on freedom of construction. In addition, in the context of general security, the article presents relevant solutions resulting from the German and English model.
\end{abstract}

Key words: Public interest, security, construction law.

\section{INTRODUCTION}

The issue of public interest is clearly visible in the legislation relating to the construction industry. The construction sector is one of the basic sectors of the economy, which demands to meet the needs of the basic areas of social life. Essentially, it is considered to be a part of stimulating the development of national economies of many countries. As is known in every state of law, state bodies and citizens are subject to the law expressed in laws and other legislative acts. This legal order is adapted to different sectors of the economy, especially in relation to construction. Applicable

PhD in Law - lecturer, graduate The John Paul II Catholic University of Lublin. 
in designated ranges is addressed to many entities conducting construction activities. The construction law is the legal basis of construction law, as a basic factor in ensuring the necessary order in the process of building and maintaining a building substance. The legal order is governed by the Construction Law ${ }^{1}$ issued on its basis and the technical-construction regulations $^{2}$. Construction activity as a sphere of human activity should be carried out for purposes related to the realization of the public interest.

\section{PUBLIC INTEREST IN CONSTRUCTION LAW}

In literature, the impossibility or even the unreasonableness of the formulation of an absolute and permanent definition of the public interest is generally emphasized. The characteristic of this concept is its relativity. This means that clarifying what the public interest must do is take into account the current social context that is susceptible to volatility over time ${ }^{3}$. In particular, the doctrine of administrative law points out the difficulties that preclude the precise clarification of public interest categories, as the requirements of the public interest are changing in almost every legal institution. However, the relativity of the concept of public interest can not justify abandoning attempts to his defining. According to J. Boć, the notion of the public interest should be seen as a tool for shaping the individual's situation, describing it as an interest that can potentially refer to many non-individualized recipients, understood collectively as one entity ${ }^{4}$. As a consequence, the public interest can be understood as a set of conditions for the good of the community, conducive to the realization of the goods of the individual, provided that they are compatible or do not directly affect the fundamental good in the public sphere ${ }^{5}$. So, the public interest

\footnotetext{
1 Consolidated text Journal of Laws of 2016, item. 1409 as amended.

2 See: L. Bar, Ład prawny w budownictwie, Państwo i Prawo 1994, no 10, p. 20.

3 M. Wyrzykowski, Pojęcie interesu społecznego w prawie administracyjnym, Warsaw 1986, p. 45.

4 J. Boć, In: Prawo administracyjne, ed. J. Boć, Wrocław 2004, p. 24.

5 K. Szczucki, Kolizja interesu prywatnego i publicznego u podstaw prokonstytucyjnej wykładni prawa karnego, In: Interes publiczny a interes prywatny w prawie, ed. T. Giaro, Warsaw 2012, p. 108.
} 
understood as the interest of the whole of society should be assessed with regard to values such as justice or security ${ }^{6}$.

In construction law there is no direct reference to public interest categories, but it is presently quite clear. As he observes Z. Niewiadomski, the purpose of the Construction Law is to protect the public interest, while respecting the individual interests that may be affected by the investment and construction process ${ }^{7}$. In terms of material standards, this is expressed primarily in ensuring the investor's right to build property and to impose obligations on the participants in the construction process, whose implementation secures the respect of the public interest and the legitimate interests of third parties ${ }^{8}$.

According to the Constitutional Tribunal, in the context of construction law, the public interest manifests itself in particular in ensuring the architectural and spatial order and security of the users of building objects, including those built without permission. It should be emphasized that proper balancing of the private and public interest is a guarantee of the proportionality of the limitation of individual rights in order to achieve the public interest ${ }^{9}$. The collision of interests and therefore the need to weigh them is characteristic of relations governed by construction law, in which the public interest, the investor's interest and the rights of third parties arising from their rights in the property neighboring the real estate investor ${ }^{10}$. The boundaries of these rights and interests, particularly in urban areas, are defined by building regulations and other legal acts

6 See: judgment of the Provincial Administrative Court in Warsaw of 8 February 2005, III SA/Wa 1471/04, LEX nr 172552.

According to W. Szwajdler, the building process is an area where the interests of various entities are concentrated in a very different manner. Among such labyrinth of interests are two main types of interest: public interest and individual interest. W. Szwajdler, Ochrona prawna interesu indywidualnego w procesie budowlanym, Toruń 1993, p. 16.

8 Z. Niewiadomski, In: Prawo budowlane. Komentarz, ed. Z. Niewiadomski, Warsaw 2011, pp. 5-6.

9 See: judgment of the Constitutional Tribunal of 13 February 2001, K 19/99, OTK 2001, no 2, item 30; judgment of the Constitutional Tribunal z 25 November 2003, K 37/02, OTK-A 2003, no 9, item 96.

10 Today, however, dominate opinion both interests as being equally protected, were the role of the administrator is the ability to balance. P.J. Suwaj, Konflikt interesów w administracji publicznej, Warsaw 2009, pp. 33-34. 
issued on the basis of and in the enforcement of this law or regulations issued for the protection of the environment. Outside of these borders, as the Supreme Court stated, "the protests of citizens expressing their personal views, expectations, postulates, wishes, etc. as to a particular spatial planning policy, mutual relations between planned investments and the sphere of their individual notions of the conditions of normal existence, leisure, use of nature, etc. These expectations, wishes and postulates should be taken into account when granting a building permit and to be taken into due consideration if this does not preclude the legitimate interest of the investor himself and the economic and social considerations in which the local authorities self-government administration are fully sovereign. Failure to take them into account can not, however, constitute grounds for questioning the legality, is the legality of a building permit" ${ }^{11}$. In the interests of third parties should also be used article 7 of the Code of Administrative Procedure which obliges the public administration organs to take care of the public interest and the legitimate interests of citizens when dealing with the matte ${ }^{12}$. The rule laid down in this provision applies in all cases in which the case was entrusted with the so-called. This is what happens when the norm of law does not provide for an obligation of a specific behavior of the body, but the possibility of choosing the way of settling the case $^{13}$. As he observes M. Zakrzewska, the public interest in the investment and construction process should be decided by the administration, but with the wide participation of interested individuals and social groups ${ }^{14}$.

In order to achieve the public interest, the legislature is designed to provide mechanisms that ensure that public authorities have sufficient au-

11 Judgment of the Supreme Court of 16 January 1992, III ARN 42/91, OSN 1993, no 3, item 42 .

12 Judgment of the Constitutional Tribunal of 20 April 2011 r., Kp 7/09, OTK-A 2011, no 3, item 26.

13 A. Matan, Zasada uwzględnienia z urzędu interesu społecznego i słusznego interesu obywateli w świetle orzecznictwa sądowego, In: Zasady prawa. Materiały konferencyjne, eds. C. Martysz, A. Matan, Z. Tobor, Bydgoszcz-Katowice 2007, p. 142.

14 M. Zakrzewska, Ochrona środowiska w procesie inwestycyjno-budowlanym, Warsaw 2010, p. 181; As pointed out by E. Ochendowski, one of the features of public administration should be its focus on safeguarding the public interest. E. Ochendowski, Prawo administracyjne. Część ogólna, Toruń 2004, p. 22. 
thority to enforce public order and enforce public interest. This issue is of key importance in relation to the state - a non-public entity (eg investor), where they should be regulated precisely. Not only the law, but also the responsibilities of each party to the relationship.

The issues of public interest in construction law can be seen in four dimensions. The first involves freedom of assembly, second in terms of compliance. The third refers to the regulation of construction activity. Fourthly, the issue of public interest can not ignore the themes of the socalled " the construction industry or the competent public administration organs performing their functions in the construction industry ${ }^{15}$.

\section{SECURITY OF BULDING OBJECTS}

Generally by security, you can define a state in which there are no threats ${ }^{16}$. The essential feature of the notion of security is the lack of a threat to the good of the human person, which gives rise to the possibility of the normal functioning of the individual in society, in particular the preservation of life, health, property, the autonomy of the enjoyment of all perpetrators of personal rights enshrined in the constitution and other laws, which is ensured by state bodies with competent competences ${ }^{17}$. Security as one of the goods subject to legal protection is not defined in any national legal act. Only in the doctrine and literature of the subject is this term differently defined and attributed to it various semantic capacities ${ }^{18}$.

Protection of security is one of the objectives of the state, which consists in reversing the dangers threatening the state, organized social groups and individual units ${ }^{19}$. Public security is to be understood as a state in

15 See: A. Żurawik, Interes publiczny w prawie gospodarczym, Warsaw 2013, p. 376.

16 S. Pieprzny, Administracja bezpieczeństwa i porządku publicznego, Rzeszów 2008, p. 11 .

17 H. Zięba-Załucka, Konstytucyjne aspekty bezpieczeństwa, In: Studia Iuridica Lublinensia Volume XXII. Księga jubileuszowa dedykowana profesor Ewie Gdulewicz w siedemdziesięciolecie urodzin, eds. R. Mojak, W. Skrzydło, Lublin 2014, p. 415.

18 Ibidem, p. 417.

19 D. Gatner, Policja administracyjna (studium z teorii myśli administracyjnej), Organizacja - Metody - Technika 1988, no 8-9, p. 28. 
which the general public, individually unmarried, living in a state and society, is in no danger of danger, regardless of the source of it ${ }^{20}$. Ensuring security is one of the overriding aims of the Construction Law. An example of such protection is the introduction of basic requirements that must be met in the construction process. These requirements apply to foreseeable impacts in terms of carrying capacity and stability, fire security, occupational security, environmental protection, noise and vibration protection, adequate hygiene and health conditions, occupational safety and health conditions and the safety and health conditions of persons on site. The above requirements should ensure the achievement of objectives that, in principle, focus on ensuring an adequate level of structural, fire safety and usability for people and property and adequate protection of health and the environment ${ }^{21}$. Because ensuring the security of property users is considered a superior value and therefore the owner or manager is obliged to take all measures to ensure that ${ }^{22}$. Security care is one of the tasks of public authority and the requirement addressed to citizens, expressed in the Constitution of the Republic of Poland of 2 April $1997^{23}$. According to article 5 of the Constitution of the Republic of Poland, protects the independence and inviolability of its territory, ensures freedom and human and civil rights and the security of citizens, protects the national heritage and ensures environmental protection, guided by the principle of sustainable development. The security of buildings objects may also be considered as a component of state security within the meaning of article 31 paragraph 3 of the Constitution of the Republic of Poland. Security building objects is an element of such concepts as public security and public health. The threat to the safety of construction works can endanger human life and health and economic and economic risks. Thus, the effects of insufficient security of building objects may affect not only citizens, but also the state. The aspiration to satisfaction at the highest possible level is an essential element of human existence treated both as

20 E. Ura, Pojęcie ochrony bezpieczeństwa i porządku publicznego, Państwo i Prawo 1974, no 2, p. 80.

21 S. Serafin, Prawo budowlane. Komentarz, Warsaw 2006, p. 131.

22 Judgment of the Provincial Administrative Court in Kielce of 19 January 2007, II SA/Ke 544/06, LEX nr 604142.

23 Journal of Laws No 78, item. 483 as amended. 
a unitary and a social being. A significant part of satisfying with the need for security is a variety of situations, events and processes with which an is dealing investor, owner or manager of a building object ${ }^{24}$. The necessity to care for security can be the basis for the restriction of freedom of the building, which is an important public interest that justifies interference in one of the fundamental freedoms of the human person. The security of building objects is therefore a prerequisite for limiting freedom construction. Restrictions on freedom construction are intended to protect values such as: the security of life and property, the protection of health and the condition of the environment, and the accessibility of facilities for people with disabilities ${ }^{25}$. These values are expressed in the provisions of construction law and in the technical and construction regulations. These values are protected at each of the four stages of the building process, namely the design, construction, maintenance and demolition of the building. Construction law requires security at the site and the building. Security concerns people and property ${ }^{26}$. According to article 5 construction law, the requirements relating to the design, construction, use and maintenance of the building have been defined. This provision states that, when designing and constructing a building, taking into account its expected life and the requirements laid down by law, and in the light of the principles of technical knowledge, the following should be ensured in particular:

1) fulfillment of basic requirements concerning: safety of construction, fire safety, safety, appropriate hygienic and health conditions and environmental protection, protection against noise and vibration, energy savings and adequate thermal insulation baffles;

2) ability to maintain proper technical condition;

3) appropriate occupational health and security conditions;

24 See: W. Fehler, Bezpieczeństwo przestrzeni publicznej, In: Bezpieczeństwo publiczne w przestrzeni publicznej, ed. W. Fehler, Warsaw 2010, p. 16.

25 See: judgment Supreme Administrative Court of 25 January 2010, II OSK 143/09, LEX nr 597275; judgment Supreme Administrative Court of 12 December 2014, II OSK 89/13, LEX nr 1519434.

26 M. Błażewski, Ochrona wartości w procesie budowlanym, In: Wartości w prawie administracyjnym. V Krakowsko-Wrocławskie Spotkanie Naukowe Administratywistów, ed. J. Zimmermann, Warsaw 2015, pp. 307-308. 
4) protection of the population and environmental protection.

About security of the building object decides, in essence, its proper use, that is, its proper use and environmental protection requirements, as well as the maintenance of the object in a sound technical and aesthetic condition, preventing excessive deterioration of the performance and technical efficiency of the building object, for its security ${ }^{27}$. These requirements should ensure the appropriate level of safety of the building. The security issue is particularly noticeable in construction regulations. The basic areas regulated by construction law, related to security issues include:

1) rules for performing independent technical functions in construction as activities related to the necessity of expert evaluation of technical phenomena in the process of design, construction and use of building objects.

2) procedures for the commencement, maintenance and completion of works, as well as the use of building objects;

3 ) the rights and obligations of the participants in the building process (investor, designer, construction manager and investor supervision inspector);

4) obligations of owners or managers of buildings, concerning the maintenance of buildings in a proper technical condition;

5) the obligation to use, when performing construction works, only products with functional properties satisfying the basic requirements, admitted to trading, in accordance with separate regulations;

6) rules of procedure for construction disaster, in particular related to determining the causes and circumstances of its occurrence;

7) obligations of the architectural and construction administration and construction supervision in the scope of works and building objects;

8) penalties for breach of construction law, professional responsibility in construction and rules of conduct in cases of liability to persons performing independent technical functions.

27 D. Sypniewski, Nadzór nad procesem budowlanym, Warsaw 2011, p. 58. 


\section{SECURITY ISSUES IN BUILDING LAWS OF OTHER COUNTRIES (GERMANY, UNITED KINGDOM)}

In Germany, public building law is divided into urban law and construction supervision law. Urban law is a law that falls within the competence of the federation of federal states and municipalities ${ }^{28}$, whereas the construction supervision law is a construction law in the strict sense and it remains within the exclusive competence of the federal states, which lay down their own regulations in this respect.

In particular, security matters have been included in the construction supervision law. This law provides for formal and legal requirements for the commencement and course of construction projects ${ }^{29}$. The subject of this law is to define the conditions and rules for the implementation of construction works, so that it would meet the requirements of the public interest, which means safety and public order. The central category of public building law in Germany is the principle of construction freedom. It is guaranteed directly in art. 141 of the Constitution and treated as an element of construction of economic freedom. This principle means the possibility of unrestricted development of the plot, including its development, unless the law clearly provides otherwise. Examples of regulations prohibiting arbitrary building are the regulations of the building code $\mathrm{e}^{30}$ prohibiting locations on the parcel of dangerous devices or specific regulations, for example about access to daylight for buildings. A characteristic institution for the construction law of Germany is the extensive use of building permits. The building permit is treated as the basic security for the implementation of the urban law requirements. This institution is a link between the urban law and the construction supervision law, while underlining its preventive character ${ }^{31}$. The applicable investment rules in special areas are particularly important for security, which are areas that due to their impact on the environment are subject to special regulation

28 See: U. Battis, M. Krautzberger, R.P. Lör, Baugesetzbuch, 9. Auflage, Munich 2005, p. 2-3.

29 Z. Niewiadomski, In: Prawna regulacja procesu inwestycyjno-budowlanego. Uwarunkowania. Bariery. Perspektywy, ed. Z. Niewiadomski, Warsaw 2009, pp. 278-279.

30 Act of 27 August 1997 (BGBI I, p. 2141).

31 F. Stollman, Öffentliches Baurecht, 3. Auflege, Munich 2015, p. 213-214. 
on the part of construction law ${ }^{32}$. It should be emphasized that building permits, according to the provisions of the Spatial Order Act, can not generally be obtained in areas called free space structures. The technical rules and norms are essential for the investment process in Germany in the context of security, while the first are generally binding, while the latter are of various legal nature, but made public by building offices, become generally binding rules of construction techniques and art. At the stage of use of the construction works, the regulations on building use are of major significance. Care for security is expressed primarily through the preventive nature of the control of the investor's activities, where the basic institution is a building permit. It allows to avoid legal violations at the outset of the investment process and as such lies in both the public and private interest of the investor.

In German regulations, we deal with broad protection of the public interest. This is done by limiting solutions, and most often excluding the possibility of building particularly protected areas, especially natural ones. The spatial order is of great value in German conditions, which are often dictated by the arrangements of building plans, which integrate strongly in the way of building.

Different regulations are included in the English model. In the United Kingdom, the basic act regulating the construction process is the construction act of 1984. On its basis, there are many executive acts containing detailed technical and construction standards. Security issues have been related to the nature of activities that should be considered construction supervision, and to a lesser extent, activities in the area of architectural and building administration, for example, issuing consent before the construction process begins. Security-related activities result from the following factors: 1) from supervisory functions, where local authorities are informed only about the implementation of the construction process supervised by an independent entity (initial note) and have a limited opportunity to object to the choice of such a construction process, 2) from activities in which the construction process is directly supervised by local authorities, it is not always required to obtain a building approval for the start of the construc-

32 In Germany, special areas include areas where the location of shopping centers is planned, as well as individual facilities with a retail area exceeding $1200 \mathrm{~m}^{2}$. 
tion process. Such an obligation occurs in principle only in the case of commercial investments. In other cases, the investor makes only the construction declaration, while the local authority only takes actions in the field of construction supervision during the implementation of the investment. Construction law in the United Kingdom also provides for rulemaking in this enforcement, in which the implemented investment violates primarily technical and construction standards $s^{33}$. A special feature of supervision is the construction according to which undertaking investment without the required urban consent or investment implementation in a manner that violates the conditions set out in the consent does not constitute in itself a violation of the law. Violation of the law is only a violation of the LPA (Local Planning Authority) note as a means of supervision ${ }^{34}$.

It should be emphasized that the solutions adopted in United Kingdom in many aspects differ from the solutions in Poland and Germany. First of all, in the United Kingdom, the investment process balances various categories of both public and private interests. Developers position is particularly strong. An example is the local authorities that take prudent supervision when it concerns investments made by private or small businesses. An important supervisory instrument is a compulsory note in which the investment and the method of use used violate a particular or$\mathrm{der}^{35}$. In the British model on a wide scale there is of the administrative recognition of public authority in the sphere of determining the conditions of urban consent, which makes the British system more flexible. Particularly noteworthy is the fact that the English regulations is particularly evident attention to environmental aspects.

\section{CONCLUSIONS}

In the Polish legal system, the value that is most often referred to in the context of public interest in the field of construction is the security of users of construction works, which are an element of state security. This depen-

33 Ł. Złakowski, In: Prawna regulacja procesu..., p. 334.

34 See: J. Blackhall, Plann Law and Practice, London 2006, p. 246.

35 Ibidem, p. 250. 
dence is due to the fact that the construction sector in general is included in areas of fundamental importance to the functioning of each state. It can be argued that the public interest in construction law, as a special and specific interest, is a counterbalance to the individual interest, which seeks to protect freedom in the construction and use of a building. The necessity of ensuring the security of users of building objects results in the need to balance both interests and, consequently, to limit the freedom in the field of construction.

\section{REFERENCES:}

Bar L., 1994, Ład prawny w budownictwie, Państwo i Prawo, no 10.

Battis U., Krautzberger M., Lör R.P., 2005, Baugesetzbuch, 9. Auflage, Munich. Blackhall J., 2006, Plann Law and Practice, London.

Błażewski M., 2015, Ochrona wartości w procesie budowlanym, In: Wartości w prawie administracyjnym. V Krakowsko-Wrocławskie Spotkanie Naukowe Administratywistów, ed. J. Zimmermann, Warsaw.

Boć J., 2004, In: Prawo administracyjne, ed. J. Boć, Wrocław.

Fehler W., 2010, Bezpieczeństwo przestrzeni publicznej, [in:] Bezpieczeństwo publiczne w przestrzeni publicznej, ed. W. Fehler, Warsaw.

Gatner D., 1988, Policja administracyjna (studium z teorii myśli administracyjnej), Organizacja - Metody - Technika, no 8-9.

Matan A., 2007, Zasada uwzględnienia z urzędu interesu społecznego i słusznego interesu obywateli w świetle orzecznictwa sądowego, In: Zasady prawa. Materiały konferencyjne, eds. C. Martysz, A. Matan, Z. Tobor, Bydgoszcz-Katowice.

Modliński E., 1932, Pojęcie interesu publicznego w prawie administracyjnym, Warsaw.

Niewiadomski Z., 2009, In: Prawna regulacja procesu inwestycyjno-budowlanego. Uwarunkowania. Bariery. Perspektywy, ed. Z. Niewiadomski, Warsaw.

Niewiadomski Z., 2011, In: Prawo budowlane. Komentarz, ed. Z. Niewiadomski, Warsaw.

Ochendowski E., 2004, Prawo administracyjne. Część ogólna, Toruń.

Pieprzny S., 2008, Administracja bezpieczeństwa i porządku publicznego, Rzeszów.

Serafin S., 2006, Prawo budowlane. Komentarz, Warsaw.

Stollman F., 2015, Öffentliches Baurecht, 3. Auflege, Munich. 
Suwaj P.J., 2009, Konflikt interesów w administracji publicznej, Warsaw.

Sypniewski D., 2011, Nadzór nad procesem budowlanym, Warsaw.

Szczucki K., 2012, Kolizja interesu prywatnego i publicznego u podstaw prokonstytucyjnej wykładni prawa karnego, In: Interes publiczny a interes prywatny w prawie, ed. T. Giaro, Warsaw.

Szwajdler W., 1993, Ochrona prawna interesu indywidualnego w procesie budowlanym, Toruń.

Ura E., 1974, Pojęcie ochrony bezpieczeństwa i porządku publicznego, Państwo i Prawo, no 2.

Wyrzykowski M., 1986, Pojęcie interesu społecznego w prawie administracyjnym, Warsaw.

Zakrzewska M., 2010, Ochrona środowiska w procesie inwestycyjno-budowlanym, Warsaw.

Zięba-Załucka H., 2014, Konstytucyjne aspekty bezpieczeństwa, In: Studia Iuridica Lublinensia Volume XXII. Księga jubileuszowa dedykowana profesor Ewie Gdulewicz w siedemdziesięciolecie urodzin, eds. R. Mojak, W. Skrzydto, Lublin.

Złakowski Ł., 2009, In: Prawna regulacja procesu inwestycyjno-budowlanego. Uwarunkowania. Bariery. Perspektywy, ed. Z. Niewiadomski, Warsaw.

Żurawik A., 2013, Interes publiczny w prawie gospodarczym, Warsaw. 
